Hal : 36 - 45

\title{
Kajian:
}

Pembelajaran PPKn

\section{PENERAPAN METODE PEMBELAJARAN DISKUSI DALAM PENINGKATAN PRESTASI BELAJAR PADA KOMPETENSI DASAR MENJELASKAN MAKNA KEDAULATAN RAKYAT SISWA KELAS VIII SMP $\begin{array}{llll}\text { NEGERI } 2 & \text { KOTA PINANG KABUPATEN }\end{array}$ LABUHANBATU SELATAN TAHUN PELAJARAN 2014/2015}

\author{
Junita, Marlina Siregar
}

Prodi PPKn, Fakultas Keguruan dan Ilmu Pendidikan, Universitas Labuhanbatu Email: neetamawar@gmail.com, siregarmarlina447@gmail.com

\begin{abstract}
Abstrak
Adapun tujuan penelitian ini adalah untuk mengetahui apakah penerapan metode diskusi dapat meningkatkan prestasi belajar siswa pada pelajaran PKn pada kompetensi dasar menjelaskan makna kedaulatan Rakyat pada siswa kelas VIII SMP NEGERI 2 Kotapinang Kabupaten Labuhanbatu Selatan Tahun pelajaran 2014/2015. Metode Diskusi adalah suatu cara penyajian bahan pelajaran dimana Guru memberi kesempatan kepada para siswa (kelompok-kelompok siswa) untuk mengadakan perbincangan ilmiah guna mengumpulkan pendapat, membuat kesimpulan atau penyusunan berbagai alternatif pemecahan atau suatu masalah. Adapun lokasi peneliti ini akan dilaksanakan di SMP NEGERI 2 Kotapinang Kabupaten Labuhanbatu Selatan tahun 2014/2015 dan waktu pelaksanaan peneliti sesuai dengan jadwal pada bulan Mei s/d Juni 2015. Adapun kesimpulan dalam penelitian adalah dari hasil keseluruhan dari Angket baik dari responden maupun pihak sekolah dapat dilihat persentasi yang mendukung hipotesa sebesar $75,18 \%$. Hal ini menunjukkan penerapan metode diskusi dapat meningkatkan prestasi belajar siswa khususnya siswa di SMP NEGERI 2 Kotapinang Kabupaten Labuhanbatu Selatan tahun pelajaran 2014/2015.
\end{abstract}

Kata kunci: Penerapan, metode, diskusi, prestasi belajar 


\section{Kajian:}

Pembelajaran PPKn

\section{PENDAHULUAN}

Guru yang professional adalah Guru yang mampu memberikanpendekatan

pembelajaran ataupun metode pembelajaran yang sesuai dengan kondisi perkembangan psikologi siswa, karena pendekatan yang sesuai perkembangan psikologis siswa akan dapat menentukan proses dan hasil belajar, di samping itu kemampuan guru juga menentukan hasil belajar siswa. Kemampuan guru antara penguasaan materi.Oleh karena itu guru hendaknya tidak lagi mengajar sekedar sebagai kegiatan menyampaikan pengetahuan keterampilan dan sikap pada siswa.

Metode adalah suatu cara yang digunakan untuk mencapai tujuan yang telah ditetapkan dalam kegiatan belajar mengajar, metode diperlukan oleh guru dan penggunaannya bervariasi sesuai dengan yang ingin dicapai setelah pengajaran berakhir, seorang guru tidak akan melaksanakan tugasnya dengan baik bila dia tidak menguasai satu pun metode mengajar yang telah dirumuskan dan di kemukakan oleh para Ahli.

Banyak faktor yang mempengaruhi keberhasilan dalam belajar pendidikan kewarganegaraan menurut Herman, (2003:51). Menjelaskan bahwa proses belajar pendidikan kewarganegaraan adalah kegiatan atau usaha untuk mencapai perubahan, maka dalam belajar pendidikan kewarganegaraan tersebut siswa terlebih dahulu memahani gejala-gejala disekitar kehidupan, sebab gejala perubahan social dimasyarakat merupakan kajian utama dalam pelajaran pendidikan kewarganegaraan.

Dari penjelasan di atas dapat disimpulkan bahwa dalam belajar pendidikan kewarganegaraan terdapat faktor internal yang mempengaruhi prestasi belajar PKn tersebut, yaitu faktor pemahaman terhadap materi yang sedang berkembang mendukung pemahaman materi yang di pelajari dalam proses belajar di kelas salah satu materi pelajaran yang membutuhkan perhatian khusus mengenai pemahan konsep maupun defenisi adalah kedaulatan rakyat pada siswa SMP VIII.

Dan untuk mengembangkan cara berfikir siswa dapat menggunakan suatu teknik yaitu diskusi hal ini sesuai dengan apa yang di kemukakan oleh Subroto, (2006:67) yang mengemukakan "metode diskusi dapat menumbuhkan dan mengembangkan cara berfikir secara ilmiah".

Dalam menanamkan pemahaman pendidik kewarganegaraan, Guru tuntun mampu memberdayakan komponenkomponen yang terlibat dalam proses belajar mengajar siswa, alat yang tersedia sarana dan prasarana yang 


\section{Kajian:}

turut mengoptimalkan pelaksanaan belajar mengajar di dalam kelas serta adanya kondisi sosial di masyarakat yang dapat dijadikan contoh bagi siswa.

Melalui penggunaan metode diskusi dapat memberikan kesempatan yang seluas-luasnya kepada siswa untuk mencari pengalaman belajar sendiri, karena masing-masing siswa berbeda kemampuan dan cara belajar. (student centre), oleh sebab itu Guru harus berupaya membelajarkan siswa sesuai dengan kemampuannya melaksanakan pengalaman belajar guru bertindak sebagai pengaruh dan pembimbing, dengan melakukan sendiri proses belajarnya maka pengalaman belajarnya semakin baik.

Oleh karena itu penulis merasa tertarik meneliti tentang "Kontribusi" penerapan metode pembelajaran diskusi dalam peningkatan prestasi siswa dalam kompetensi dasar menjelaskan makna kedaulatan rakyat pada siswa kelas VII SMP Negeeri 2 Kotapinang Labuhanbatu Selatan tahun 2014/2015.

Salah satu metode yang dapat membantu para siswa meningkatkan siswa terhadap pendidikan kewarganegaraan adalah metode diskusi. Dengan metode ini akan dapat menumbuhkan rasa percaya diri siswa terhadap kemampuannya untuk menyelesaikan masalahmasalah dalam pendidikan kewarganegaraan sehingga dapat mengurangi rasa cemas terhadap pendidikan kewarganegaraan.

Subroto

(2002:45)

mengemukakan : Metode diskusi adalah suatu cara penyajian bahan pelajaran dimana guru memberi kesempatan kepada para siswa (kelompok-kelompok siswa) untuk mengadakan perbincangan ilmiah guna pengumpulan mendapat membuat kesimpulan atau penyusunan berbagai alat-alat alternatif pemecahan atau suatu masalah.

Langkah-langkah dalam metode diskusi

Lebih lanjut Subroto (2002:101) mengemukakan langkahlangkah penggunaan metode diskusi kelompok yaitu :

1. Guru mengemukakan masalah yang akan di diskusikan dan pemberian penghargaan seperlunya mengenai cara-cara pemecahannya.

2. Dengan, pemimpin guru para siswa membentuk kelompokkelompok diskusi (ketua, sekretaris, pelapor, mengatur tempat duduk ruangan, sarana dan sebagainya.

3. Para siswa berdiskusi di dalam kelompoknya masingmasing sedangkan guru berkeliling dari kelompok ke kelompok yang lain menjaga ketertiban serta memberikan 


\section{Kajian: \\ Pembelajaran PPKn}

dorongan dan bantuan

sepenuhnya agar setiap

kelompok berpartisipasi aktif dan agar diskusi berjalan lancar.

4. Kemudian tiap kelompok melaporkan hasil diskusinya hasil yang dilaporkan itu di tanggapi oleh semua siswa (terutama dari kelompok lain) guru memberi ulasan atau penjelasan terhadap laporanlaporan tersebut.

5. Akhirnya para siswa mencatat (hasil-hasil) diskusi dan guru mengumpulkan laporan hasil diskusi dari tiap-tiap kelompok sesudah para siswa mencatatnya untuk "file" kelas.

Metode diskusi juga merupakan suatu cara mengajar yang di cirikan oleh suatu keterikatan pada suatu topik atau pokok pernyataan atau problem dimana para peserta diskusi dengan jujur berusaha untuk mencapai atau memperoleh suatu keputusan atau pendapat yang disepakati bersama, diskusi sebagai metode pembelajaran lebih cocok dan diperlukan apabila guru hendak :

1. Memanfaatkan berbagai kemampuan yang ada pada siswa

2. Memberi kesempatan pada siswa untuk mengeluarkan kemampunnya
3. Mendapatkan balikan dari siswa apakah tujuan telah tercapai

4. Membantu siswa belajar berfikir secara kritis

5. Membantunya siswa belajar menilai kemampuan dan peranan diri sendiri maupun teman-teman

6. Membantu siswa menyadari dan mampu merumuskan berbagai masalah sendiri maupun dari pelajaran sekolah

7. Mengembangkan motifasi untuk belajar lebih lanjut

Kelebihan metode diskusi adalah :

1. Menyadarkan anak didik bahwa masalah dapat di pecahkan dengaan berbagai jalan dan bukan satu jalan (satu jawaban saja)

2. Menyadarkan anak didik bahwa dengan berdiskusi mereka saling mengemukakan pendapat secara kontruksi sehingga dapat diperoleh keputusan yang lebih baik.

3. Membiasakan anak didik untuk mendengarkan pendapat orang lain.

4. Mendidik siswa untuk belajar mengemukakan pikiran atau pendapat

5. Memberikan kesempatan kepada siswa untuk memberi 


\section{Kajian: \\ Pembelajaran PPKn}

pembelajaran-pembelajaran

dari sumber data.

6. Memberi ksempatan siswa untuk menghayati pembaharuan suatu problem bersama-sama.

7. Melatih siswa untuk berdiskusi di bawah asuhan guru.

8. Merangsang siswa untuk ikut mengemukakan pendapat sendiri, menyetujui atau menentang pendapat temantemannya.

9. Pembina suatu perasaan tanggung jawab mengenai suatu pendapat, kesimpulan, atau keputusan yang akan telah diambil.

10. Mengembangkan rasa solidaritas/toleransi terhadap pendapat bervariasi atau mungkin bertentangan sama sekali.

\section{METODE PENELITIAN}

Lokasi penelitian dekat dengan tempat tinggal penulis sehingga dapat mengurangi dana dan waktu. Penulis telah memahami dan mengenal lokasi tersebut dan mengenal beberapa guru di SMP Negeri 2 Kotapinang Kabupaten Labuhanbatu Selatan sehingga memungkinkan memperlancar penelitian.

Waktu peneliti dilakukan di mulai dari bulan Mei s/d Juni 2015 di
SMP Negeri 2 Kotapinang Kabupaten Labuhanbatu Selatan tahun pelajaran 2014/2015.

Populasi adalah keseluruhan objek yang di teliti.Mengingat lokasi peneliti begitu luas, maka peneliti mengambil populasi dan sampel dari kelas saja dan yang menjadi populasi adalah seluruh siswa kelas VIII SMP Negeri 2 dengan perincian 250 siswa.

Sampel adalah bagian dari populasi yang dipandang perlu dapat mewakili populasi untuk dijadikan sumber data atau informasi dalam suatu peneliti. Batasan pengertian sampel menurut Nawawi (2003:141)

\section{HASIL PENELITIAN DAN PEMBAHASAN}

Dalam memperoleh data yang diperlukan untuk peneliti ini penulis memperolehnya dengan pengisian angket yang diberikan kepada responden secara terarah kepada 34 orang.Angket yang peneliti sebarkan ternyata mendapat sambutan dan ini terlihat dari pengumpulan data yang diberikan dengan jawaban-jawaban responden.

Dengan demikian angket berhasil 100\%.Penulis mengambil data dengan pentabulasian jawaban pertanyaan yang diajukan pada waktu pengisian angket.Adapun pentabulasian tersebut adalah sebagai berikut.

Dari item Quisioner tentang perlunya penerapan pembelajaran 


\section{Kajian:}

metode diskusi untuk meningkatkan hasil belajar siswa di sekolah terlihat yang memilih option a sebanyak 28 responden sebesar $(81,2 \%)$ yang memilih option $\mathrm{b}$ sebanyak 5 responden sebesar $(15,7 \%)$ yang memilih option c sebanyak 1 responden sebesar $(3,1 \%)$. Sehingga penulis mengambil kesimpulan bahwa tanggapan responden terhadap perlunya penerapan pembelajaran metode diskusi untuk meningkatkan hasil prestasi belajar siswa di sekolah.

Dari item Quisioner kedua tentang seringnya guru menggunakan metode pembelajaran diskusi dalam mengerjakan tugas di sekolah atas yang diketahui memilih option a sebanyak 27 responden sebesar $(79,41 \%)$ yang memilih option b sebanyak 6 responden sebesar $(18,8 \%)$ yang memilih option c sebanyak 1 responden sebesar $(3,1 \%)$. Dapat disimpulkan bahwa responden lebih banyak memilih seringnya guru menggunakan metode pembelajaran diskusi dalam mengerjakan tugas di sekolah untuk meningkan hasil belajar siswa.

Dari item Quisioner ketiga tentang penggunaan metode diskusi sebagai penunjang kegiatan belajar di atas yang memilih option a sebanyak 29 responden sebesar $(91,7 \%)$ yang memilih option b sebanyak 4 responden sebesar $(11,76 \%)$ yang memilih option c sebanyak 1 responden sebesar $(3,1 \%)$ tidak menggunakan metode diskusi sebagai penunjang kegiatan belajar. Maka dapat disimpulkan siswa menggunakan metode diskusi sebagai penunjang kegiatan belajar.

Tabel item Quisioner keempat tentang dengan penerapan metode diskusi minat dan motivasi belajar semakin rajin dan meningkat di sekolah memperlihatkan bahwa yang memilih option a sebanyak 18 responden sebesar $(52,92 \%)$ siswa dedngan penerapan metode diskusi minat dan motivasi belajar siswa semakin rajin dan meningkat di sekolah. Sedangkan yang memilih option b sebanyak 10 responden sebesar $(31,2 \%)$ mengatakan kadangkadang menggunakan dengan penerapan metode diskusi minat dan motivasi belajar siswa semakin rajin dan meningkat di sekolah dan memilih option c sebanyak 6 responden sebesar $(18,8 \%)$ yang mengatakan dengan metode diskusi minat dan motivasi belajar siswa tidak semakin rajin dan meningkat di sekolah.

Pada item Quisioner lima tentang penerapan metode pembelajaran metode pembelajaran diskusi sangat berpengaruh terhadap peningkatan prestasi belajar siswa di sekolah dapat memperlihatkan bahwa penerapan metode pembelajaran diskusi sangat berpengaruh terhadap peningkatan prestasi belajar siswa disekolah SMP Negeri 2 Kotapinang Kabupaten 


\section{Kajian:}

Labuhanbatu Selatan. Ini terbukti dari jawaban yang memilih option a sebanyak 32 orang sebesar (100\%).

Dari item Quisioner enam tentang keaktifan siswa mengikuti evaluasi terhadap prestasi hasil belajar diketahui 28 jawaban responden yang memilih option a sebanyak (82,35\%). Mengatakan siswa aktif mengikuti evaluasi terhadap prestasi belajar siswa setiap akhir materi pembelajaran di sekolah.Kemudian 6 responden memilih option b sebanyak $(18,8 \%)$ mengatakan siswa kurang aktif mengikuti evaluasi terhadap prestasi belajar siswa setiap akhir materi pembelajaran di sekolah dan 1 responden yang memilih option c sebanyak $(3,1 \%)$ mengatakan siswa tidak aktif mengikuti evaluasi terhadap prestasi belajar siswa setiap akhir materi pelajaran di sekolah.

Pada item Quisioner tujuh
tentang minat siswa dalam
menggunakan penerapan metode diskusi di sekolah menunjukkan bahwa minat siswa dalam menggunakan penerapan metode diskusi di sekolah sangat tinggi, hal ini terbukti dari banyaknya responden memilih jawaban option a sebanyak 27 orang sebesar $(79,41 \%)$ kemudian 6 responden memilih option b sebanyak (18,8\%) mengatakan kurang berminat dalam menggunakan penerapan metode diskusi di sekolah, dan 1 responden yang memilih option c sebanyak
$(3,1 \%)$ tidak berminat menggunakan penerapan metode diskusi di sekolah SMP Negeri 2 Kotapinang tahun pelajaran 2014/2015.

Pada item Quisioner delapan dengan penerapan metode diskusi suasana belajar semakin menyenangkan dan menarik bagi siswa di sekolah meunujukkan bahwa dengan penerapan metode diskusi suasana belajar mengajar semakin menyenangkan dan menarik bagi siswa di sekolah dalam kegiatan belajar, 18 responden memilih option a sebanyak $(52,94 \%)$ dan 10 responden yang memilih option $b$ sebanyak $(31,2 \%)$ yang mengatakan kadang-kadang dengan penerapan metode diskusi suasana belajar mengajar semakin menyenangkan dan menarik bagi siswa di sekolah dalam kegiatan belajar, dan 6 responden yang memilih option $\mathrm{c}$ sebanyak (18,8\%) mengatakan dengan penerapan metode diskusi suasana belajar mengajar senmakin menyenangkan dan menarik bagi siswa di sekolah dalam kegiatan belajar.

Pada item Quisioner kesembilan keaktifan siswa dalam melakasanakan kegiatan belajar dengan penerapan metode diskusi di sekolah. Menunjukkan bahwa keaktifan siswa dalam melaksanakan kegiatan belajar dengan penerapan metode diskusi di sekolah, terlihat dari jawaban responden yang memilih option a sebanyak 24 orang 


\section{Kajian:}

Pembelajoran PPKn

sebesar $(70,58 \%) .6$ responden yang memilih option b sebesar $(17,64 \%)$ yang mengatakan kadang-kadang siswa dalam melaksanakan kegiatan belajar dengan penerapan metode diskusi di sekolah untuk belajar di sekolah dan 4 responden yang memilih option c sebesar $(11,76 \%)$ mengatakan tidak aktif untuk belajar dengan penerapan metode diskusi di sekolah.

Pada item Quisioner sepuluh tentang apakah siswa diberi teguran jika tidak melaksanakan metode pembelajaran diskusi dengan baik ?membuktikan siswa diberi teguran jika tidak melaksanakan metode pembelajaran diskusi dengan baik, terbukti dengan sebanyak 18 responden memilih option a sebesar ( $31,2 \%$ ) responden memilih option $b$ sebesar $10(29,41 \%) 6$ responden memilih option c sebesar $(17,64 \%)$.

Pada item Quisioner sebelas tentang upaya yang dilakukan siswa melalui penerapan metode diskusi untuk meningkatkan prestasi belajar di sekolah. Menunjukkan bahwa keaktifan siswa dalam melaksanakan kegiatan belajar dengan penerapan metode diskusi di sekolah, terlihat dari jawaban responden yang memilih option b sebesar $(17,64 \%)$ yang mengatakan baik upaya siswa dalam melaksanakan kegiatan belajar dengan penerapan metode diskusi untuk meningkatkan prestasi belajar siswa di sekolah dan 4 responden yang memilih option c sebesar
$(11,76 \%)$ mengatakanmengatakan sedikit baik upaya siswa dengan penerapan metode diskusi untuk meningkatkan prestasi belajar di sekolah.

Pada item Quisioner duabelas dengan penerapan metode diskusi di sekolah prestasi belajar siswa semakain meningkatakan menunjukkan bahwa penerapan metode diskusi di sekolah prestasi belajar siswa semakin meningkatan, terlihat dari jawaban respon yang memilih option a sebanyak 32 orang sebesar (100\%), tidak ada respondeen memilih option $\mathrm{b}$ dan $\mathrm{c}$, Penulis dalam hal ini berkesimpulan bahwa dengan kontribusi penerapan metode pembelajaran diskusi dapat meningkatkan prestasi belajar pelajaran PKn pada kompetisi makna kedaulatan rakyat di kelas VIII SMP Negeri 2 Kotapinang tahun pelajaran 2014/2015.

\section{KESIMPULAN}

Dari hasil keseluruhan angket baik dari responden maupun pihak sekolah dapat dilihat dari presentasi yang mendukung hipotesa sebesar 75, 185, hal ini menunjukkan penerapan metode diskusi dapat meningkatkan prestasi belajar siswa khususnya siswa di SMP Negeri 2 Kotapinang Kabupaten Labuhanbatu Selatan tahun pelajaran 2011/2012. 


\section{Kajian:}

Pembelajaran PPKn

Respon siswa terhadap metode pembelajaran diskusi pada umumnya positif, hal ini dapat dilihat berdasarkan analisis angket pelajaran banyak siswa melakukan tindakan yang tidak relevan.

Prestasi bellajar semakin meningkat dengan kontribusi dengan penerapan pembelajaran metode diskusi pada kompetensi dasar menjelaskan tentang makna kedaulatan rakyat dikelas VIII SMP Negeri 2 Kotapinang.

Minat dan motivasi siswa semakin meningkat dan membaik dengan kontribusi penerapan pembelajaran metode diskusi pada kompetisi dasar menjelaskan tentang makna kedaulatan rakyat di kelas VIII SMP Negeri 2 Kotapinang.

Kontribusi penerapan pembelajaran metode diskusi pada kompetensi dasar menjelaskan tentang makna kedaulatan rakyat di kelas VIII SMP Negeri 2 Kotapinang sangat tepat digunakan pada materi pada mata pelajaran PKn khususnya. Di karenakan siswa lebih tertarik menggunakan metode diskusi dibandingkan dengan metode pembelajaran yang lain. Prestasi belajar siswa juga meningkatkan dengan evaluasi yang dilakukan setiap harinya.Guru PKn juga berperan aktif dalam membimbing siswa dalam menerapkan metode diskusi setiap ada tugas kelompok ysng diberikan agar siswa lebih aktif dan lebih giat untuk belajar di sekolah maupun dirumah.

\section{DAFTAR PUSTAKA}

Arikunto Suharsimi. 1998. Prosedur Peneliti Suatu Pendekatan Praktek. Jakarta: Rineka Cipta

Thabrani. 1992. Fungsi dan Peran Guru Dalam Pendidikan, Jakarta: PT. Gaja Grafindo Persada.

Astuti. 2006. Hubungan orang tua dan Sekolah dalam Pendidikan. Medan: Firma Maju.

Darajat, Zakiah. 1997. Psykologi Perkembangan Anak. Jakarta : PT. Gaja Grafindo Persada.

Hamalik, Omar. 2001. Proses Belajar Mengajar. Bandung : PT. Aksara Saiful Bahri. 2000. Belajar dan Faktor-faktor yang mempengaruhinya. Jakarta : Bina Aksara.

Shavie. 2007. Psykologi Perkembangan Remaja. Jakarta : PT. Raja Grafindo Persada.

Sudjana. 2002. Metode Statistik.Bandung : Tarsito.

Sunarwijaya. 2007. Peranan Orang Tua dalam Pendidkan Anak. Jakarta : Gramedia. 
Hal : 36 - 45

\section{Kajian: \\ Pembelajaran PPKn}

Simanjuntak, M. 2006. Proses

Belajar Mengajar Suatu

Pendekatan. Bandung : Alfabeta 